\title{
Financial Market Shocks during the Great Depression
}

\author{
Alycia Chin \\ Missaka Warusawitharana* \\ Board of Governors of the Federal Reserve System
}

\begin{abstract}
This study examines the effect of shocks observed in financial markets on output and employment during the Great Depression. We present three main findings. First, an adverse financial shock leads to a decline in the manufacturing sector's output and employment that peaks about 11 months afterward. Next, this shock has a much greater impact on the durables sector than the nondurables sector. Last, continuing financial market weakness in 1933 and 1934 may have restrained the recovery from the Great Depression. The findings suggest that financial market weakness contributed to the length and depth of the Great Depression, and that this occurred mainly through the investment channel. In addition, we use the estimates from the Great Depression data to evaluate the effect of recent financial market disruptions.
\end{abstract}

October 22, 2009

\footnotetext{
${ }^{*}$ We thank Mark Carlson, Joshua Gallin, Jonathan Rose, Robert Vigfusson, Egon Zagrasek, and seminar participants at the Philadelphia Fed and the Federal Reserve Board for comments. The views expressed in this paper are ours and do not reflect the views of the Board of Governors of the Federal Reserve System or its staff. Contact: Division of Research and Statistics, Board of Governors of the Federal Reserve System, Mail Stop 97, 20th and C Street NW, Washington, DC 20551. m1mnw00@frb.gov, (202)452-3461.
} 


\section{Introduction}

Recent events have highlighted the effect of financial system disruptions on the macroeconomy. In a seminal paper, Bernanke (1983) argued that disruptions to the financial system affect the real economy by increasing the cost of credit intermediation. A large subsequent literature has examined this channel with an emphasis on the effect of disruptions to the banking system 1 In addition to bank failures, the Great Depression was also a period of significant financial market stress, which may have contributed to its severity. Motivated by this observation, we present evidence relating financial market shocks to real economic outcomes 2

We examine the effect of shocks observed in the financial markets using vector auto-regressions (VARs) on monthly data for output, employment, wholesale prices, and a financial market variable. We use the short-run identification method in the analysis with the financial variable ordered last. This captures the effect of an innovation to the financial market variable that is orthogonal to current shocks to productivity, real wages, and nominal prices - all of which have been shown to have played a role during the Great Depression 3 We analyze the effect of financial market shocks using impulse response functions constructed from the VAR estimates.

The financial market variables we use in the study include stock prices, credit spreads, and the total issuance of stocks and bonds. Thus, we measure financial market conditions using both price and quantity data. Although innovations to prices and quantities are correlated, examining then in parallel enables us to provide a broader picture of the relationship between financial market variables and economic outcomes.

Using this approach, we find that an adverse shock to the financial market variable results in a decrease in manufacturing sector output and total hours. This decrease peaks about 11 months after the shock. Quantitatively, a residual one standard deviation shock to the financial variable leads to a peak output decline of about 3 to 4 percent and a peak total hours decline of about 2 percent. These results indicate that shocks observed in financial markets have a lagged impact on manufacturing sector outcomes. The financial market variable accounts for about 20 percent of the forecast error variance for output and total hours. Cole, Ohanian, and Leung (2007) find that stock price shocks account for about 25 percent of output variation using a DSGE approach with

\footnotetext{
${ }^{1}$ See Calomiris and Mason (1997), Calomiris and Mason (2003), and Carlson and Mitchener (2009), among others.

${ }^{2}$ Other papers that have examined the effect of shocks in the financial markets using more recent data include Gilchrist, Yankov, and Zakrajsek (2009) and Christiano, Motto, and Rostagno (2009).

${ }^{3}$ See Cole and Ohanian (1999), Bordo, Erceg, and Evans (2000), and Friedman and Schwartz (1963), respectively, for evidence on the role of productivity shocks, real wage rigidity, and monetary shocks during the Great Depression.
} 
annual data on a panel of countries from 1929 to 1933.

The theoretical models that underpin our analysis highlight the role of financial markets for financing investment. The agency cost models of Bernanke and Gertler (1989), Carlstrom and Fuerst (1997), and Bernanke, Gertler, and Gilchrist (1999) demonstrate that a decline in net worth or an increase in borrowing costs reduces the ability of entrepreneurs to finance investment by lowering their available collateral. Although we do not have monthly data on investment, durables goods sector output provides a good proxy for investment demand. We next examine whether financial market shocks have a greater effect on the durables goods sector than the non-durables good sector.

We collect new data for the employment and output of the durables and non-durables goods sectors from various Federal Reserve Bulletins. The Federal Reserve Bulletin of August 1940 presents data on industrial output obtained by aggregating output indices across industries. The Federal Reserve Bulletin of October 1938 presents a similar employment series. The data indicate that the durables good sector suffered greater declines during the Great Depression than the nondurables sector, with peak to trough declines of output and employment of about 77 and 57 percent, respectively. In comparison, the nondurables sector had peak to trough output and employment declines of about 34 and 32 percent, respectively.

VAR analyses on the durables good sector indicate that an adverse shock to a financial variable leads to peak employment and output declines of about 3 and 6 percent, respectively. In comparison, the peak declines for the nondurables sector are all less than 2 percent. This suggests that financial market shocks have a much greater effect on the durables good sector than the non-durables sector, consistent with the investment-channel highlighted in the agency costs literature 4 These results are consistent with the arguments of Mishkin (1978) and Romer (1989) that declines in net worth exacerbated the Great Depression by lowering the consumption of durable goods by households.

The data indicate that financial market conditions remained weak even while the broader economy was recovering strongly in 1933 and 34. The stock market declined from July 1933 to December 1934; the average credit spread over these this period was 3.3 percent, compared to 2.3 percent in the period leading up to July 1929; stock and bond issuance reached its lowest point in February 1933 and remained depressed until the spring of 1935. These findings suggest that weakness in financial markets persisted well into the recovery. Combined with our previous results, this indicates that financial market weakness may have contributed to the slow recovery from the

\footnotetext{
${ }^{4}$ Here we follow the literature by considering household and firm demand for durable goods as parts of investment. We cannot distinguish between durable goods purchases by households and business fixed investment.
} 
Great Depression, as highlighted in Cole and Ohanian (2004). Further evidence of this effect can be seen from the much sharper recovery in the non-durables goods sector as compared to the durables goods sector.

We also use our estimates from the VAR on the Great Depression to quantify the effect of financial market innovations during the recent financial crisis. We measure the effect of the crisis as the value of financial market innovations during the recent crisis times the impulse response from the VAR on the Great Depression data. This calculation indicates the the sharp declines in stock and bond prices in fall 2008 may lead to manufacturing sector total hours and output declines of 12 and 16 percent, respectively. Although imprecisely estimated, the findings suggest that adverse financial market shocks during the recent crisis may presage a sharp and persistent contraction in the manufacturing sector.

The econometric analysis relates shocks observed in financial markets to real economic outcomes. One clear drawback of this analysis is that it cannot distinguish between a true shock to the financial system and a shock to expectations about future economic outcomes that is observed in the financial system. For instance, the news shock literature - see Beaudry and Portier (2006) argues that otherwise unexplained stock price movements reflect information about future TFP. However, it is difficult to reconcile this explanation with the continuing financial market weakness observed in the early stage of the recovery from the Great Depression.

If we do capture a shock to the financial system, what may be the underlying structural shock? One possibility is that investors' risk aversion increased following the sharp dislocations associated with the Great Depression (see Cogley and Sargent (2008)). Another possibility is that the Great Depression was associated with a substantial loss of human capital in the financial services industry, leading to an increase in funding costs (see Phillipon and Reshef (2009)). Yet another possibility is that the financial market shocks reflect increases in future uncertainty (see Bloom (2009)). We investigate this possibility by using stock market volatility, constructed using daily stock return data, as a measure of economic uncertainty. Somewhat surprisingly, we find that including the uncertainty measure has no effect on our results - the negative effect of an increase in uncertainty on the real economy is orthogonal to the effect of a decrease in stock prices.

This study is organized as follows. Section 2 presents the data employed in the study. Section 3 details the econometric method. Section 4 presents the empirical findings. Section 5 uses the results to examine the effects of the recent financial crisis and Section 6 concludes. 


\section{Data}

This section discusses the data we use in our study. In order of presentation, we discuss the financial market variables, the macroeconomic aggregates, and the sectoral data. The sample period is July 1922 to June 1939. The start date was determined by the availability of data on weekly hours while the end date of the sample was chosen to avoid the effects of World War II.

\subsection{Financial market variables}

We obtain data on stock prices and credit spreads from the Historical Statistics of the United States Millenium Edition (hereafter, HSUS). We use the Standard and Poor's common stock index from the HSUS (series Cb45) as the stock price series. This series is the precursor to the widely used S\&P 500 stock index. In the subsequent analysis, we divide the stock index series by the wholesale price index to translate the stock price into real terms.

We obtain data on Baa-rated corporate bonds (series Cb59), long-term U.S. government bonds (series Cb57), and short-term U.S. government bonds (series Cb56) from the HSUS. The original data source for both interest rates was the U.S. Federal Reserve publication Banking and Monetary Statistics: 1914-1941. The credit spread employed in the study equals the log difference between the Baa bond interest rate and the long-term bond interest rate.

We obtain data on securities issuance from the NBER Macrohistory database. This database contains many series on securities issuance. For the purposes of this study, we use the series titled 'Total corporate issues, bonds, notes, and stocks, including refunding, U.S., Canadian and Foreign' as it provides a comprehensive sum of securities issuance in the U.S. capital markets 5

We construct stock market volatility using data on daily stock returns collected by Prof. G. William Schwert. This data is discussed in detail in Schwert (1990). The monthly stock volatility measure used in the study equals the monthly average of the absolute daily stock returns minus the average stock return for that month.

Figure 1 presents the financial variables employed in the study. The stock market rose dramatically through the 1920s. It began to decline sharply in the fall of 1929 and reached its lowest point in June 1932. At its trough, the stock market had declined by more than 80 percent from its peak value. Although the stock market improved with the economy, it did not return to its

\footnotetext{
${ }^{5}$ Although preferable, the database does not contain a series of securities issuance by only U.S. firms.
} 
pre-Great Depression peak level until World War II. The path for stock price movements suggests that the attendant sharp decline in net worth may have exacerbated the Great Depression.

Credit spreads exhibit a different path from stock prices during this time period. They remained low in the 1920s amidst the economic expansion. Credit spreads did not begin to rise until the fall of 1930, and then begin a steep climb to above 7.5 percent in May 1932, before beginning to decline to more normal levels. The path for credit spreads suggest that they increased partly in response to adverse economic developments during the Great Depression. However, the sharp rise in credit spreads during 1931 may have worsened the economic downturn.

The data on securities issuance indicate that they increase with stock prices during the boom period in the 1920s. Somewhat surprisingly, securities issuance does not decline sharply until well into the Great Depression. However, it remains very low from 1932 to 1935, even as the overall economy began a strong recovery. This indicates that financial market conditions remain depressed well into the economic recovery, possibly due to a substantial destruction of human capital in the financial services industry.

The stock market volatility series captures the sudden stock market crash in the fall of 1929 . Although volatility declines immediately following the crash, it subsequently increases steadily over the downturn and continues to remain elevated until 1934. This indicates that economic uncertainty, as measured by stock price volatility, increased fairly sharply during the Great Depression. Keynes (1936) argues that this increase in uncertainty lead to lower investment and output.

Overall, the figures suggest that while financial crises did not cause the Great Depression, they may have contributed to its severity. The impact of sharp stock price declines on net worth and the high real interest rate faced by corporate borrowers would have sharply limited the scope for borrowing during the downturn. Furthermore, continuing financial market weakness in 1933 and 34 may have restrained the recovery from the Great Depression.

\subsection{Macroeconomic data}

We obtain data on the wholesale price index and the seasonally adjusted industrial production of manufacturers from various Federal Reserve Bulletins. The industrial production series tracks the quantity produced by manufacturing firms during this time period. We use the wholesale price index as it tracks price changes in the manufacturing sector.

We obtain data on manufacturing employment from the HSUS (series Cb46). This series tracks the employment of production workers in the manufacturing sector. We also obtain average weekly 
hours of production workers from the HSUS (series Cb48). This series begins in January 1932. We extend this series back using linear interpolation of monthly data on average weekly hours for wage-earners from the HSUS (series Cb49) on annual data on average hours for manufacturing workers from the Employment, Hours, and Earnings, United States, 1909-946 In the VARs, we construct total hours as manufacturing employment times weekly hours.

Figure 2 plots these macroeconomic series. The industrial production series highlights the dramatic drop in output during the Great Depression - manufacturing output declined by more than 50 percent from peak to trough. Output recovered and reached its trend level by 1937 before declining again in the subsequent downturn. The path for manufacturing sector employment follows the output series, but the peak to trough decline for employment is lower than the corresponding drop in output.

The average weekly hours of production workers declined along with output and employment during the Great Depression. This demonstrates that firms adjusted their labor force on both the intensive and extensive margin. The decline in average hours may also reflect pressure on firms to avoid wage cuts 7 Somewhat surprisingly, the weekly hours series remains depressed well into the recovery period. Taken together, the data on output, employment, and hours indicate that labor productivity increased over the 1930s as argued by Field (2003, 2006).

One central feature of the Great Depression was the steep decline in the average price level. The wholesale price index declined by nearly 40 percent from August 1929 to March 1933. In comparison, the consumer price index fell by only about 25 percent, reflecting smaller declines in the price of services such as rent and utilities. The wholesale price index fails to reach its 1920s level until the end of the Great Depression. Such a sharp decline in the price level would amplify financial shocks by increasing the debt burden for outstanding loans 8

\subsection{Durable and nondurable goods sectors}

The investment-based channel highlighted by the agency cost models of Bernanke and Gertler (1989) and Carlstrom and Fuerst (1997) suggests that financial shocks should have a greater effect

\footnotetext{
${ }^{6}$ This calculation implicitly assumes that monthly variation in weekly hours for wage-earners, for which we have monthly data, reflects the monthly variation in weekly hours for all manufacturing workers, for which we have only annual data.

${ }^{7}$ Bordo, Erceg, and Evans (2000) argue that nominal wage rigidity exacerbated the Great Depression.

${ }^{8}$ Fisher (1933) argues that debt deflation was a primary cause of the Great Depression. Temin (1976) argues in favor of other factors, including a sharp consumption decline in 1930. Olney (1990) documents that a high debt burden restrained consumption once the Great Depression set in.
} 
on the durables goods sector than the nondurables sector. We collect data on the output and employment of these sectors to examine whether financial shocks had a greater impact on the durables sector.

We obtain data on the output of the durables and nondurables sectors from the August 1940 publication of the Federal Reserve Bulletin. This reports revised index values for monthly output dating back to 1923. The indices were computed as weighted averages of various manufacturing industry groups.

We obtain data on the employment of these two sectors from the October 1938 publication of the Federal Reserve Bulletin. We extended the series to June 1939 using subsequent Federal Reserve Bulletins. The employment indices were also constructed as weighted average of various industry groups.

Figure 3 plots the output and employment of these two sectors over the sample period. Output and employment of the durables sector declined steeply over the Great Depression, falling from peak to trough by about 77 and 57 percent, respectively. In comparison, the nondurables sector was less affected during the Great Depression, with peak to trough declines of output and employment of about 33 percent each. The figures also suggest a much stronger recovery in the output and employment of the nondurables goods sector. The sharper decline and slower recovery of the durables good sector indicate that the durables good sector was more strongly affected during the Great Depression. This could be due to adverse financial market conditions limiting the ability of businesses and households to finance durable goods purchases.

\section{Empirical method}

This section details the empirical method used in the analysis. We use VARs to study the effect of shocks observed in the financial market on output and total hours of the manufacturing sector as well as the durable and nondurable goods sectors. We subsequently discuss the robustness of our findings to changes in the empirical specification.

Each VAR system includes four variables ordered as: the wholesale price index, manufacturing output, manufacturing total hours, and one financial system variable 9 We estimate three separate VARs to separately capture the effect of innovations to stock prices, credit spreads, and securities

\footnotetext{
${ }^{9}$ Anari, Kolari, and Mason (2005) use a similar method to study the impact of the quantity of money tied up in the banking system due to bank liquidations during the Great Depression.
} 
issuance. We identify the effect of financial system innovations using short-run restrictions 10 As the financial system variable is ordered last, the results capture the effect of shocks observed in the financial system that are orthogonal to contemporaneous shocks to prices, output, and total hours. The inclusion of the price index in the VAR takes into account the effect of monetary shocks during the Great Depression as emphasized by Friedman and Schwartz (1963). And innovations to output and total hours take into account potential productivity shocks and shocks to wage mark-ups during this period.

We use a similar specification for the VAR systems for the durables and nondurable goods sectors. We cannot quite replicate the above analysis due to the lack of separate price indices on each sector and the absence of data on weekly hours for each sector. The sectoral VARs consist of the wholesale price index, sectoral output, sectoral employment, and one financial system variable. The ordering of the VAR is the same as above.

We take log-differences of all variables to ensure stationarity in the VARs. The estimation uses 13 lags in each of the VARs to capture potential deep lags in the system. We check the stability of the VAR coefficients using an eigenvalue test. Using the VAR estimates, we construct cumulative impulse response functions for a residual one standard deviation shock to the financial variable. The figures report these cumulative impulse response over a 24 month period. We use a bootstrap procedure to construct the 95 percent confidence interval for the impulse responses 11

\section{Results}

This section reports the impulse response functions obtained from the VAR analyses. It also details the various robustness checks we carry out.

\subsection{Stock prices}

Figure 4 reports the results from the VAR with the real stock price as the financial market variable. Panel A presents the cumulative impulse response function over 24 months for a residual one

\footnotetext{
${ }^{10}$ See Stock and Watson (2001) for a discussion of identification strategies in VARs.

${ }^{11}$ The bootstrap algorithm is as follows. Compute the residuals from the VAR estimation. Draw a random sample with replacement from the residual vectors. Using the initial observations and the bootstrapped residuals, construct a new sample data set. Estimate the VAR on this bootstrapped data set and construct the impulse response function. Generate 200 such bootstrap impulse response functions and use them to construct the confidence interval.
} 
standard deviation increase in stock prices. Panel B presents the corresponding forecast error variance decomposition.

The impulse responses indicate that an increase in stock prices is followed by an increase in the manufacturing sector's total hours and output. Total hours and output increase by about 1 percent a few months after the impulse. The peak response occurs about 11 months after the impulse at the peak total hours and output have increased by about 3 and 4 percent, respectively. These increases are statistically and economically significant. Note that although the impulse response of the change in total hours and output fades after 12 months, the cumulative impulse response, shown here, does not fade.

The forecast error variance decompositions indicate that stock price innovations account for about 5 percent of the forecast variance in output and total hours after 3 months. The variance contribution increases to a little under 20 percent after 12 months.

These findings indicate that, consistent with the agency cost models of financial shocks, a stock price innovation affects output and total hours in the manufacturing sector. Furthermore, the impulse peaks with a noticeable lag, as would be the case if the stock price innovation propagates through an investment channel. Beaudry and Portier (2006) present a related finding using more recent data. They argue that stock price changes capture the arrival of news about future TFP. However, given the magnitude of the stock price changes during the Great Depression, it is debatable whether these changes reflect the arrival of news about future productivity. A news shock interpretation would also be inconsistent with the findings of Field (2003) that the 1930s was a decade of rapid productivity growth.

\subsection{Credit spreads}

Figure 5 reports the results from the VAR with the credit spread as the financial market variable. Panel A presents the cumulative impulse response functions and Panel B presents the forecast error variance decompositions.

The impulse responses show that total hours and output decline following an increase in credit spreads. The peak declines of 2 and 3 percent, respectively, occur about 11 months afterward, similar to the response to stock price innovations. The similarity in the impulse response reflects the high correlation between innovations to stock prices and credit spreads from August 1929 
onward 12 However, total hours and output respond much less in the months immediately following an innovation to credit spreads. The forecast error variance decomposition attributes more than 20 percent of the forecast variance in total hours and output to shocks observed in credit spreads.

As with the results in the previous section, these findings are consistent with the main implications of the agency cost models of financial shocks. An increase in the cost of obtaining credit leads to a lagged negative effect on output and total hours. However, we cannot eliminate the possibility that these results reflect changes in expectations about future economic outcomes.

\subsection{Securities issuance}

Figure 6] presents the findings from the VAR with total securities issuance as the financial market variable. Panel A presents the cumulative impulse response functions and Panel B presents the forecast error variance decompositions.

The impulse responses indicate that an innovation to securities issuance is followed by an increase in the output and employment of the manufacturing sector. The impulse response peaks about 11 months afterward, similar to that observed with stock prices and credit spreads. Although the total hours peak response is significant at the 95 percent level, the output response is not significant. The results indicate that an improvement in financial markets, as measured by the quantity of securities issued, leads to a lagged improved in manufacturing sector outcomes. Given that a major purpose for issuing securities is to finance investment, these findings are consistent with the investment channel highlighted in the agency costs literature. Although we can not exclude the possibility that our results capture changes in expectations, the very low levels of securities issuance observed in the early stage of the recovery casts doubt on this alternate explanation. As before, the forecast error variance decomposition attributes a significant portion of the variation in output and employment to financial market shocks.

The correlation between changes to stock prices and securities issuance over the sample period is only -0.02. This indicates that the impulse responses obtained with the securities issuance series is not merely a replication of the results obtained with stock prices.

\footnotetext{
${ }^{12}$ The correlation between changes in stock prices and credit spreads equals - 0.77 for the sample after August 1929 . The comparable value for the sample prior to August 1929 is only -0.11 .
} 


\subsection{Durable and nondurable goods sectors}

We next examine whether innovations in financial markets have a stronger impact on the durable goods sector than the nondurables sector. Purchases of durable goods by firms and households are often financed by borrowing. Thus, a financial shock would be expected to have a greater effect on the durables sector, consistent with the investment-channel highlighted in the agency costs literature.

Figure 7 plots the results from the VARs on the durable goods sector. Panels A, B, and C present the cumulative impulse response function over 24 months obtained using stock prices, credit spreads, and securities issuance as the financial market variable, respectively. The sample period extends from January 1923 to June 1939.

The impulse responses indicate that financial market price innovations have a marked effect on the durables goods sector. A one standard deviation increase in stock prices leads to employment and output increases of 4 and 9 percent, respectively. The corresponding impulse responses for innovations to credit spreads equals 3 and 7 percent, respectively. These peak impulses are statistically significant, and substantially larger than those observed for the manufacturing sector as a whole. However, securities issuances leads to a weaker impulse, particularly for durables sector employment 13

Figure 8 plots the corresponding results from the VARs for the nondurable goods sector. The impulse responses to stock prices and credit spreads for this sector have a similar profile as those the durables sector 14 However, the impulse responses for the two sectors are of different orders of magnitude. The peak responses for employment and output in the nondurables sector barely exceed 2 percent. Similar to the durables sector, innovations to securities issuance have no significant effect on the nondurables sector.

Taken together, these results indicate that shocks observed in financial markets have a much greater impact on the durables good sector. This finding is consistent with the investment-based channel emphasized in the agency costs literature. A shock to the marginal efficiency of investment highlighted by Justiniano, Primaceri, and Tambalotti (2008) would also generate a similar disparate impact on the durables sector. However, the micro-foundations for an investment shock during the

\footnotetext{
${ }^{13}$ The impulse responses for securities issuance becomes significant if we limit the sample to December, 1937 , to avoid the effects of the subsequent downturn.

${ }^{14} \mathrm{An}$ increase in credit spreads leads to declines in output and employment within 3 months for the nondurables sector but not the durables sector.
} 
Great Depression are unclear, whereas a financial market shock may reflect a shock to risk premia or human capital in the financial services sector.

Section 2.1 documented that financial market conditions remained depressed in late 1933 and 1934. The above results imply that this continuing weakness in financial markets contributed to the very slow recovery in the durables sector documented in Section 2.3. This finding suggests that increased funding costs due to financial market weakness hindered the recovery from the Great Depression.

\subsection{Robustness}

We examine the robustness of our results to changes in the empirical specification over a range of dimensions. Changing the ordering of the non-financial variables over the five other possible permutations has no effect on the results. We also change the number of lags in the VARs from 13 to 7,10 , or 16 . We obtain similar results as before with 10 or 16 lags. However, our results change when we use only 7 lags: the impulse response to stock prices peaks after a few months and we no longer find a significant effect for impulses to credit spreads or securities issuance. This change reflects the effect of the deep lags in the VAR system. We also add the short-term interest rate on U.S. treasuries as an additional variable in the VAR system. This has no effect on the impulse response for stock prices. However, the impulse response to credit spreads now has two peaks - one after 11 months and another after 18 months. In general, the robustness checks for the comparison between the durable and nondurable goods sectors follow a similar pattern to that observed for the manufacturing sector.

The analysis presented in the study employed the financial market variables one at a time. We replicate our analysis including stock prices, credit spreads, and securities issuance in the VAR. The resulting impulse responses depend somewhat on the ordering of the financial variables. For all six specifications, innovations to stock prices have a significant effect on output and employment, though the effect varies in strength. The impulse response to innovations to securities issuance have a similar profile, though they cease to become statistically significant when securities issuance is ordered after stock prices. The impulse response to credit spreads depends on whether it is ordered before or after stock prices. An impulse to credit spreads that is orthogonal to stock prices has no clear effect. The impulse response is similar to that reported in Section 4.2 when the ordering is reversed. 
Another possibility we examine is whether our financial market impulses are reflecting increases in uncertainty. We use stock market volatility constructed from daily stock returns as a measure of uncertainty. Figure 9 presents the impulse responses from a VAR with the wholesale price index, manufacturing output, manufacturing total hours, stock market volatility, and stock prices. The impulse response for stock prices is little changed from Figure 4 . This indicates that the stock price effect we capture does not reflect a change in uncertainty about the future economy. Interestingly, an increase in uncertainty also has a negative effect on manufacturing sector output and total hours as argued by Bloom (2009) and Bloom, Floetotto, and Jaimovich (2009).

The results reported in this study were obtained using VARs with log-differences of the nonstationary variables. An alternate approach involves estimating the systems using vector error correction (VEC) models on the levels data. We repeat the analysis using VEC models with the the number of co-integrating equations varying with the variables in each system. We obtain similar impulse response profiles using the VEC as those obtained with the VAR. However, the VEC results attribute a greater share of the forecast variance to stock prices and a lesser share to credit spreads than the corresponding VAR estimates. As before, we find a much stronger impulse for the durables good sector than the nondurables sector.

We examine whether the financial variables used in the study Granger cause output and employment. We find that stock prices and credit spreads Granger cause output and employment for the manufacturing sector as a whole as well as the durables and nondurables sectors. However, securities issuance Granger causes manufacturing sector output but not total hours.

\section{$5 \quad$ Effect of recent financial market disruptions}

We next use the results from the VARs during the Great Depression to study the effect of financial market shocks during the fall of 2008. As detailed in Swagel (2009), financial markets were subject to a series of unexpected events during this period, which lead to sharp adverse movements in stock prices and credit spreads. The previous results suggest that these shocks may have a significant impact on the real economy.

We quantify the effect of the recent financial market shocks using a simple, albeit arguable, approach. We construct fitted values for financial market variables for 2008 using point estimates from the corresponding VARs estimated on the Great Depression data. The realization of each financial market variable minus the corresponding fitted value yields an estimate of financial market 
innovations. The estimated effect of these innovations equals the financial market innovation times the corresponding impulse response from the VAR on the Great Depression data 15 This calculation quantifies the effect of these financial market innovations absent other shocks or policy interventions. Thus, the results can not be viewed as a forecast for either output or employment. However, this method does provide a metric to gauge the intensity of the financial market disruptions during fall 2008.

Table 1 presents the estimated effect of financial market innovations during September and October, 2008. The estimated effect on output and employment are reported at the peak impulse response period of 11 months and further on at 18 months. The results indicate that the financial market disruptions are estimated to have an economically large effect on the manufacturing sector 16 At the peak, these innovations are estimated to result in output and total hours declines in the manufacturing sector of about 16 and 12 percent, respectively. These negative effects are expected to be quite persistent, lasting well into 2010. The estimated effects for the durables sector are even greater, reflecting the larger impulse response values. The wide confidence intervals around the estimates for both sectors reflect the degree of uncertainty entailed in such a calculation.

\section{Conclusion}

This study examines the effect of shocks observed in the financial markets on the output and employment of the manufacturing sector. We find that an adverse shock in financial markets leads to lower output and employment, with the peak effect occurring about 11 months afterward. We also document that adverse financial market shocks have a much greater effect on the durables sector than the non-durables sector. Although our method cannot attribute a causal link, these findings are consistent with the agency cost models of financial shocks, where increased borrowing costs lead to reductions in future output and employment.

Although our results pertain to the Great Depression, they may be of some value for thinking about the ongoing recession. Romer (2009) compares the financial strains and policy responses during the Great Depression and the current recession. If a similar relationship holds, our findings

\footnotetext{
${ }^{15}$ This approach assumes that data from the Great Depression is helpful for evaluating recent events. An alternate approach would be to simply use data up to the recent financial crisis to construct these impulse responses. However, it is not clear how informative this approach would be as the period leading up to the recent financial crisis lacks any comparable event. Indeed, much of the discussion following the financial crisis revolved around the prevention of a recurrence of the Great Depression (see Wessels (2009)).

${ }^{16}$ The estimated effect using the total issuance series is much weaker. This is partly due to the fact that total stock, bond, and commercial paper issuance did not decline as sharply as stock and bond prices did over this time period.
} 
suggest that the financial market stress in the fall of 2008 could have a significant negative effect on the economy in 2009 and beyond. On the other hand, the results also suggest that the policy interventions taken by the Federal Reserve System and the U.S. Treasury to mitigate financial market disruptions may have helped prevent an even sharper economic downturn. 


\section{References}

Anari, Ali, James Kolari, and Joseph Mason, 2005, Bank asset liquidation and the propagation of the U.S. Great Depression, Journal of Money, Credit, and Banking 37, 753-773.

Beaudry, Paul, and Franck Portier, 2006, Stock prices, news and economics fluctuations, American Economic Review 96, 1293-1307.

Bernanke, Ben S., 1983, Nonmonetary effects of the financial crisis in the propagation of the Great Depression, American Economic Review 73, 257-276.

Bernanke, Ben S., and Mark Gertler, 1989, Agency costs, net worth, and business fluctuations, American Economic Review 79, 14-31.

Bernanke, Ben S., Mark Gertler, and Simon Gilchrist, 1999, The financial accelerator in a quantitative business cycle framework, in John B. Taylor, and Michael Woodford, eds.: Handbook of Macroeconomics (Elsevier, Amsterdam, The Netherlands ).

Bloom, Nick, 2009, The impact of uncertainty shocks, Econometrica 77, 623-685.

Bloom, Nick, Max Floetotto, and Nir Jaimovich, 2009, Really uncertain business cycles, Stanford University working paper.

Board of Governors of the Federal Reserve System, Federal Reserve Bulletin, various issues.

Board of Governors of the Federal Reserve System, 1976, Banking and Monetary Statistics, 19141941.

Bordo, Michael D., Christopher J. Erceg, and Charles L. Evans, 2000, Money, sticky wages, and the Great Depression, American Economic Review 90, 1447-1463.

Bureau of Labor Statistics, 1994, Employment, Hours, and Earnings, United States, 1909-94.

Calomiris, Charles W., and Joseph R. Mason, 1997, Contagion and bank failures during the Great Depression: The June 1932 Chicago banking panic, American Economic Review 87, 863-883.

Calomiris, Charles W., and Joseph R. Mason, 2003, Consequences of bank distress during the Great Depression, American Economic Review 93, 937-947. 
Carlson, Mark, and Kris James Mitchener, 2009, Branch banking as a device for discipline: Competition and bank survivorship during the Great Depression, Journal of Political Economy $117,165-210$.

Carlstrom, Charles T., and Timothy S. Fuerst, 1997, Agency costs, net worth, and business fluctuations: A computable general equilibrium analysis, American Economic Review 87, 893910.

Christiano, Lawrence J., Roberto Motto, and Massimo Rostagno, 2009, Financial factors in economic fluctuations, Northwestern University working paper.

Cogley, Timothy, and Thomas J. Sargent, 2008, The market price of risk and the equity premium: A legacy of the Great Depression?, Journal of Monetary Economics 55, 454-476.

Cole, Harold L., and Lee E. Ohanian, 1999, The Great Depression in the United States from a neoclassical perspective, Federal Reserve Bank of Minneapolis Quarterly Review 23, 2-24.

Cole, Harold L., and Lee E. Ohanian, 2004, New Deal policies and the persistence of the Great Depression: A general equilibrium analysis, Journal of Political Economy 112, 779-816.

Cole, Harold L., Lee E. Ohanian, and Ron Leung, 2007, The international Great Depression: Deflation, productivity, and the stock market, Working paper, University of Pennsylvania.

Field, Alexander J., 2003, The most technologically progressive decade of the century, American Economic Review 93, 1399-1413.

Field, Alexander J., 2006, Technological change and U.S. productivity growth in the interwar years, Journal of Economic History 66, 203-236.

Fisher, Irving, 1933, The debt deflation theory of Great Depressions, Econometrica 1, 337-357.

Friedman, Milton, and Anna J. Schwartz, 1963, A Monetary History of the United States, 18671960. (Princeton University Press Princeton, NJ).

Gilchrist, Simon, Vladimir Yankov, and Egon Zakrajsek, 2009, Credit market shocks and economic fluctuations: Evidence from corporate bond and stock markets, Forthcoming, Journal of Monetary Economics. 
Justiniano, Alejandro, Giorgio E. Primaceri, and Andrea Tambalotti, 2008, Investment shocks and business cycles, Federal Reserve Bank of Chicago working paper.

Keynes, John M., 1936, The General Theory of Employment, Interest and Money. (Macmillan Press London, UK).

Mishkin, Frederic S., 1978, The household balance sheet and the Great Depression, Journal of Economic History 38, 918-937.

Olney, Martha L., 1990, Avoiding default: The role of credit in the consumption collapse of 1930, Quarterly Journal of Economics 114, 319-335.

Phillipon, Thomas, and Ariell Reshef, 2009, Wages and human capital in the U.S. financial industry: 1909-2006, New York University working paper.

Romer, Christina D., 1989, The Great Crash and the onset of the Great Depression, Quarterly Journal of Economics 105, 597-624.

Romer, Christina D., 2009, Back from the brink, Federal Reserve Bank of Chicago, Chicago, IL.

Schwert, William G., 1990, Indexes of U.S. stock prices from 1802 to 1987, Journal of Business 63, 399-426.

Stock, James H., and Mark Watson, 2001, Vector autoregressions, Journal of Economic Perspectives $15,101-115$.

Swagel, Philip, 2009, The financial crisis: An inside view, Brookings Papers on Economic Activity $1,1-63$.

Temin, Peter, 1976, Did Monetary Forces Cause the Great Depression? (W. W. Norton New York, NY).

Wessels, Davis, 2009, In Fed We Trust: Ben Bernanke's War on the Great Panic. (Crown Business New York, NY).

Historical Statistics of the United States, Millennial Edition, http://hsus.cambridge.org/HSUSWeb, Cambridge University Press. 
Table 1: Estimates on the impact of financial shocks during fall 2008

Panel A: Manufacturing sector

\begin{tabular}{|c|c|c|c|c|}
\hline & \multicolumn{2}{|c|}{11 months } & \multicolumn{2}{|c|}{18 months } \\
\hline & Output & Total hours & Output & Total hours \\
\hline Stock prices & -15.6 & -11.6 & -12.6 & -9.5 \\
\hline & {$\left[\begin{array}{ll}-6.1 & -25.1\end{array}\right]$} & {$\left[\begin{array}{ll}-3.8 & -19.4\end{array}\right]$} & {$\left[\begin{array}{ll}-1.3 & -23.9\end{array}\right]$} & {$\left[\begin{array}{ll}0.0 & -19.0\end{array}\right]$} \\
\hline Credit spreads & -17.7 & -12.7 & -8.5 & -6.1 \\
\hline & {$\left[\begin{array}{ll}-31.0 & -4.4\end{array}\right]$} & {$\left[\begin{array}{ll}-23.8 & -1.6\end{array}\right]$} & {$\left[\begin{array}{ll}-22.6 & 5.6\end{array}\right]$} & {$\left[\begin{array}{ll}-18.6 & 6.4\end{array}\right]$} \\
\hline Total issuance & $\begin{array}{c}-2.0 \\
{\left[\begin{array}{ll}-4.5 & 0.4\end{array}\right]}\end{array}$ & $\begin{array}{c}-2.3 \\
{[-4.3-0.4]}\end{array}$ & 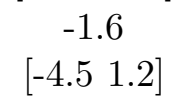 & 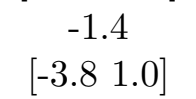 \\
\hline
\end{tabular}

Panel B: Durable goods sector

\begin{tabular}{|c|c|c|c|c|}
\hline & \multicolumn{2}{|c|}{11 months } & \multicolumn{2}{|c|}{18 months } \\
\hline & Output & Employment & Output & Employment \\
\hline Stock prices & -44.5 & -20.3 & $\begin{array}{c}-32.4 \\
\end{array}$ & $\begin{array}{l}-19.3 \\
\end{array}$ \\
\hline & {$[-23.8-65.2]$} & {$\left[\begin{array}{lll}-9.6 & -30.9\end{array}\right]$} & {$\left[\begin{array}{ll}-6.8 & -58.0\end{array}\right]$} & {$\left[\begin{array}{ll}-3.9 & -34.8\end{array}\right]$} \\
\hline Credit spreads & -46.0 & -16.0 & -26.0 & -10.1 \\
\hline & {$\left[\begin{array}{lll}-72.6 & -19.3\end{array}\right]$} & {$\left[\begin{array}{lll}-30.4 & -1.5]\end{array}\right.$} & {$\left[\begin{array}{ll}-54.4 & 2.4\end{array}\right]$} & {$[-26.26 .1]$} \\
\hline Total issuance & $\begin{array}{c}-4.1 \\
{[-10.01 .8]}\end{array}$ & 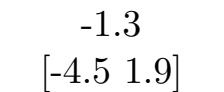 & $\begin{array}{c}-2.1 \\
-8.8 \quad 4.6]\end{array}$ & $\begin{array}{c}-0.6 \\
-4.83 .5]\end{array}$ \\
\hline
\end{tabular}

The table presents the estimated effect of innovations to financial market variables during September and October of 2008. The corresponding 95 percent confidence intervals are reported below in square parenthesis. The reported values correspond to estimated percentage changes in the manufacturing and durables goods sectors arising from the financial market innovations. The financial market innovations are obtained as the residual from fitting recent data to the corresponding VAR estimates from the Great Depression data. The estimated effects on output and employment and the confidence intervals equal the financial market innovation times the corresponding impulse response values from the VAR. 
Figure 1: Stock prices, credit spreads, securities issuance, and stock market volatility

Stock prices

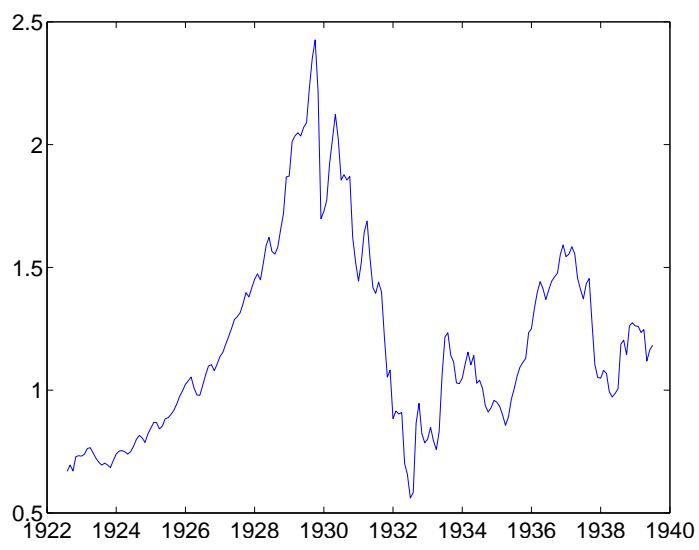

Securities issuance

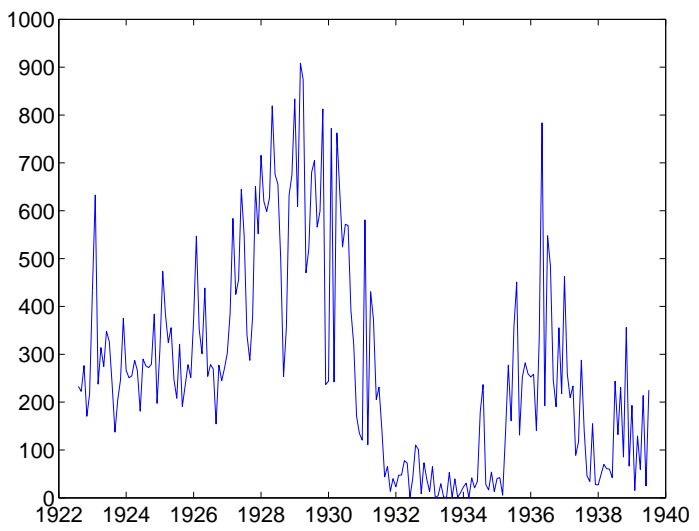

Credit spreads

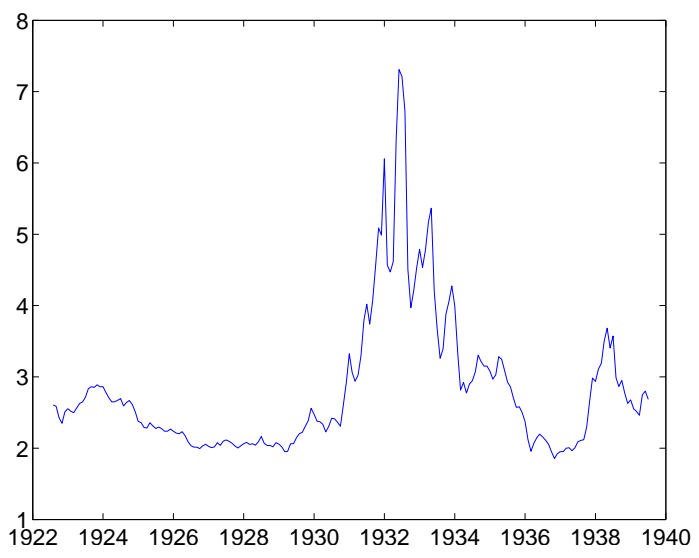

Stock market volatility

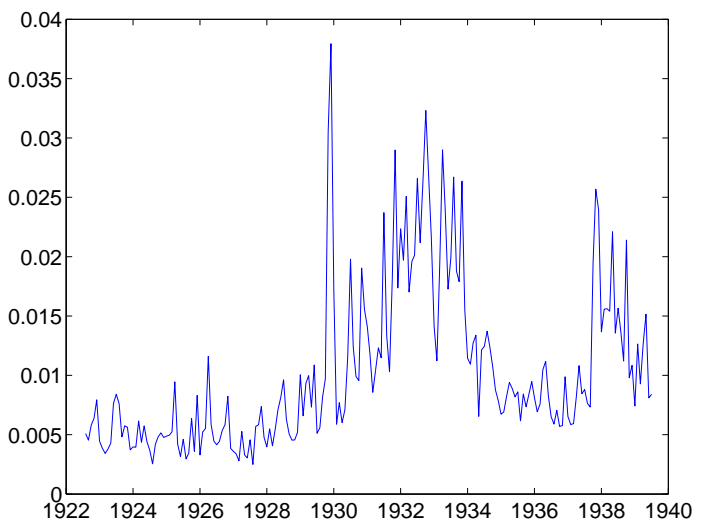

The figure plots monthly data on the real stock price, credit spread, securities issuance, and log of bank suspensions. The real stock price equals the index price of a precursor to the S\&P 500 divided by the wholesale price index. The credit spread equals the log difference between the interest rate on Baa-rated corporate bonds and long-term U.S. Treasury bonds. The securities issuance series equals the sum of stocks and bonds issued in U.S. capital markets. The stock market volatility measure is constructed as the monthly average of the absolute value of daily stock returns minus the monthly return. The sample period is July 1922 to June 1939. The source data for stock prices and credit spreads are obtained from the Historical Statistics of the United States, Millennial Edition. The source data for securities issuance is obtained from the NBER Macrohistory database. The stock market volatility is constructed from daily stock return data. 
Figure 2: Production, prices, and employment

Industrial production

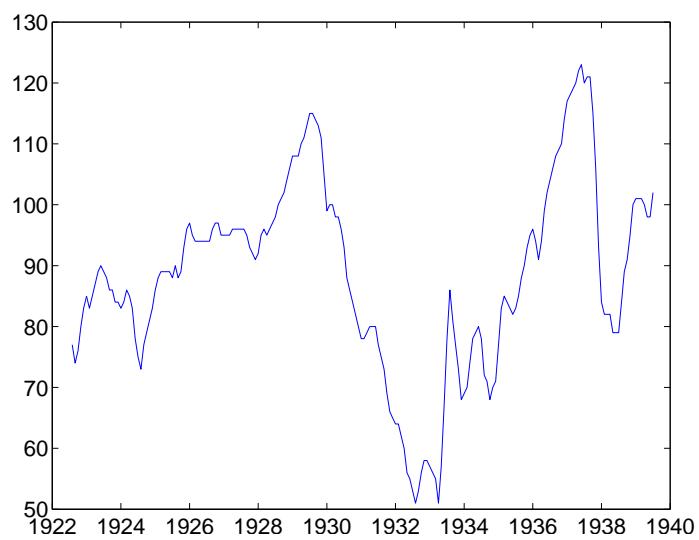

Weekly hours

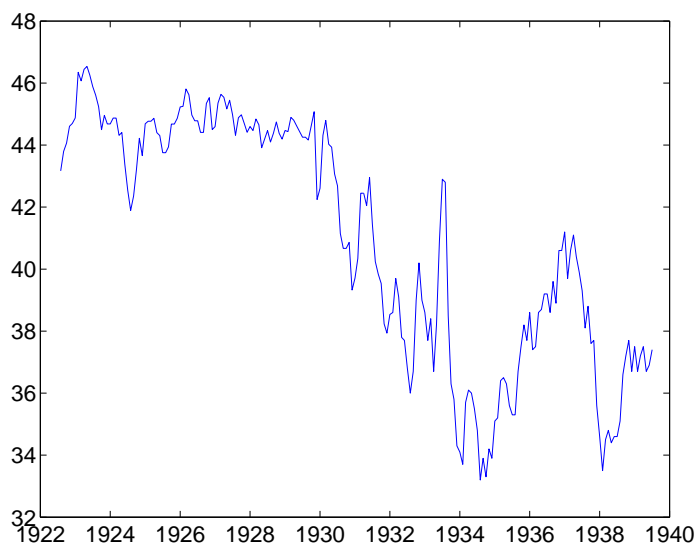

Manufacturing employment

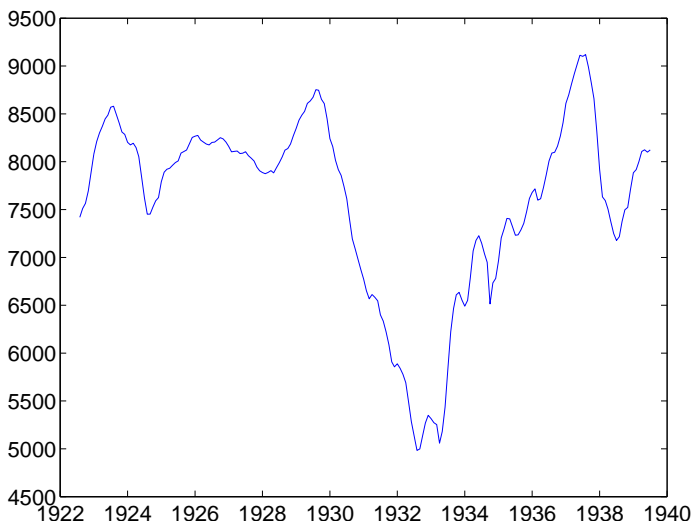

Wholesale price index

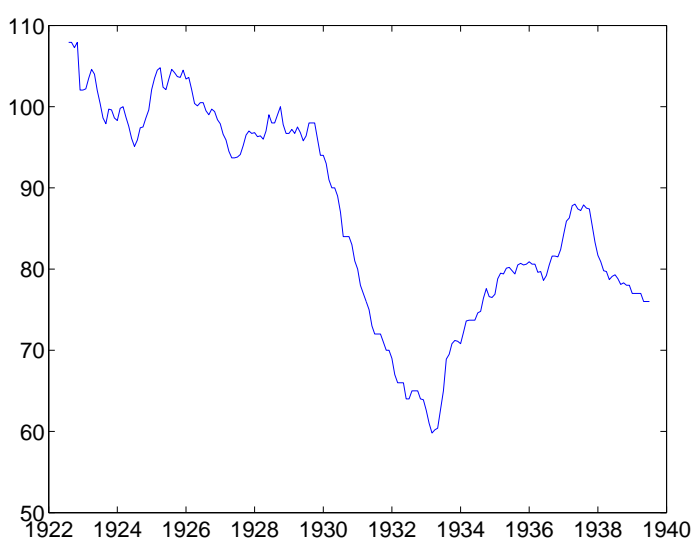

The figure plots monthly data on industrial production of the manufacturing sector, manufacturing sector employment, average weekly hours, and the wholesale price index. The industrial production series is a quantity index of the output of the manufacturing sector constructed by the Federal Reserve System. The manufacturing sector employment equals the number of manufacturing production workers in thousands. The weekly hours series tracks the average weekly hours of production workers. The wholesale price index measures the prices of industrial goods and commodities. The sample period is July 1922 to June 1939. The data are obtained from various Federal Reserve Bulletins and the Historical Statistics of the United States, Millennial Edition. 
Figure 3: Durable and nondurable goods sectors

Durables sector output

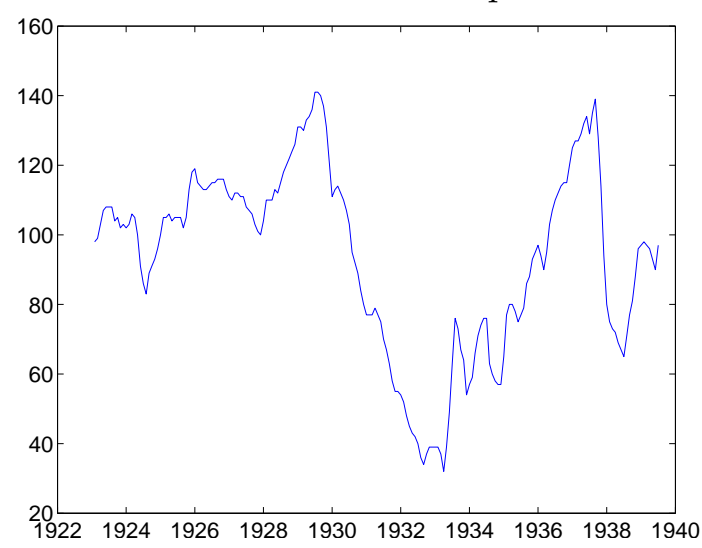

Nondurables sector output

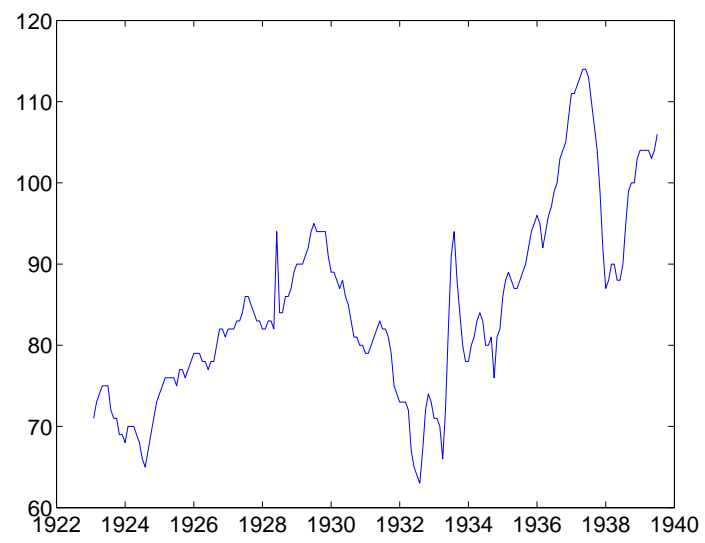

Durables sector employment

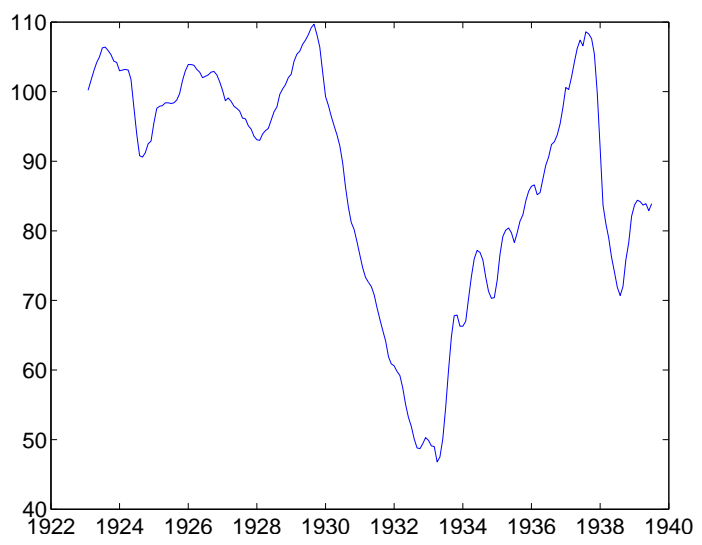

Nondurables sector employment

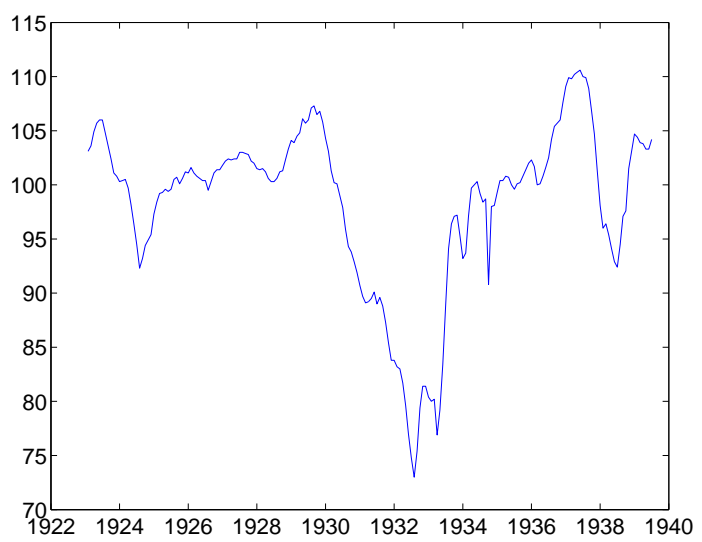

The figure plots monthly output and employment indices of the durable and nondurable goods sectors during the Great Depression. The sample period is January 1923 to June 1939. The data are obtained from various Federal Reserve Bulletins. 
Figure 4: Responses to stock prices

Panel A: Impulse response function (total hours and output)

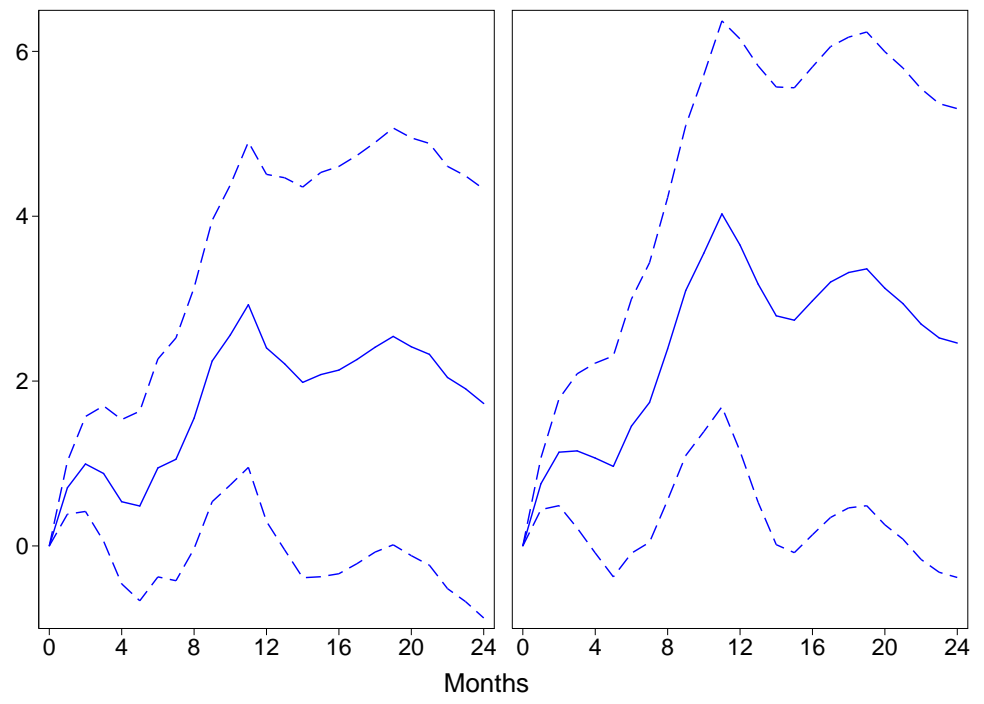

Panel B: Forecast error variance decomposition

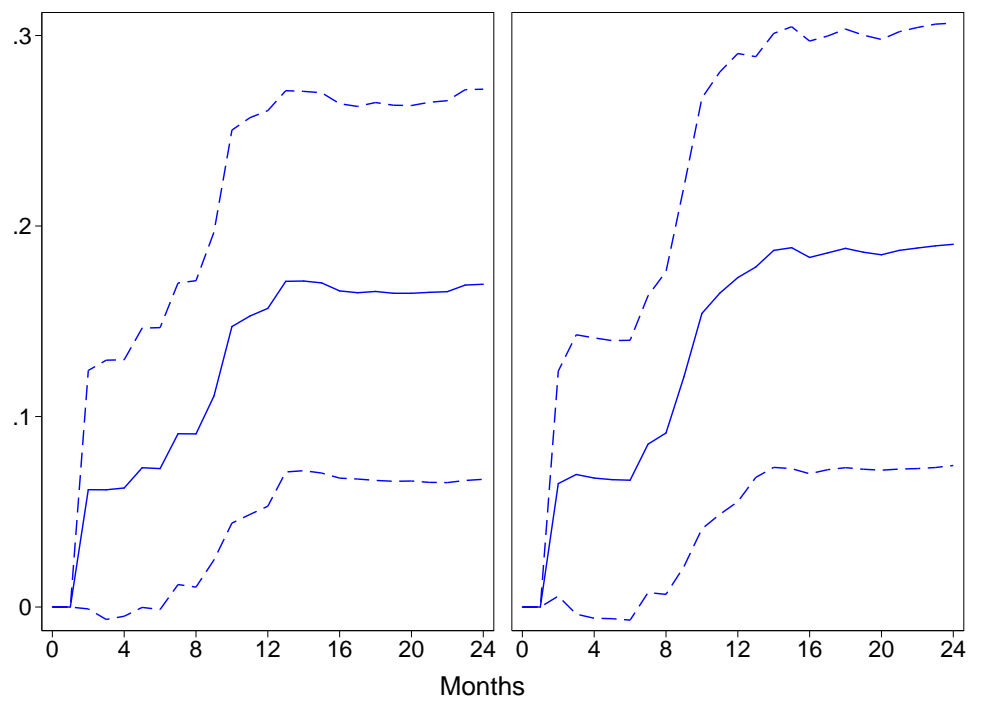

The figure plots the cumulative impulse response function and the forecast error variance decomposition from a VAR on monthly data for the wholesale price index, manufacturing output, manufacturing total hours, and real stock prices. Total hours equals employment times weekly hours. The left panels present the response of total hours and the right panels present the response of output. The sample period is July 1922 to June 1939. The shocks are identified based on shortrun restrictions with the stock price series ordered last. The dashed-lines represent bootstrapped 95 percent confidence intervals. 
Figure 5: Responses to credit spreads

Panel A: Impulse response function (total hours and output)

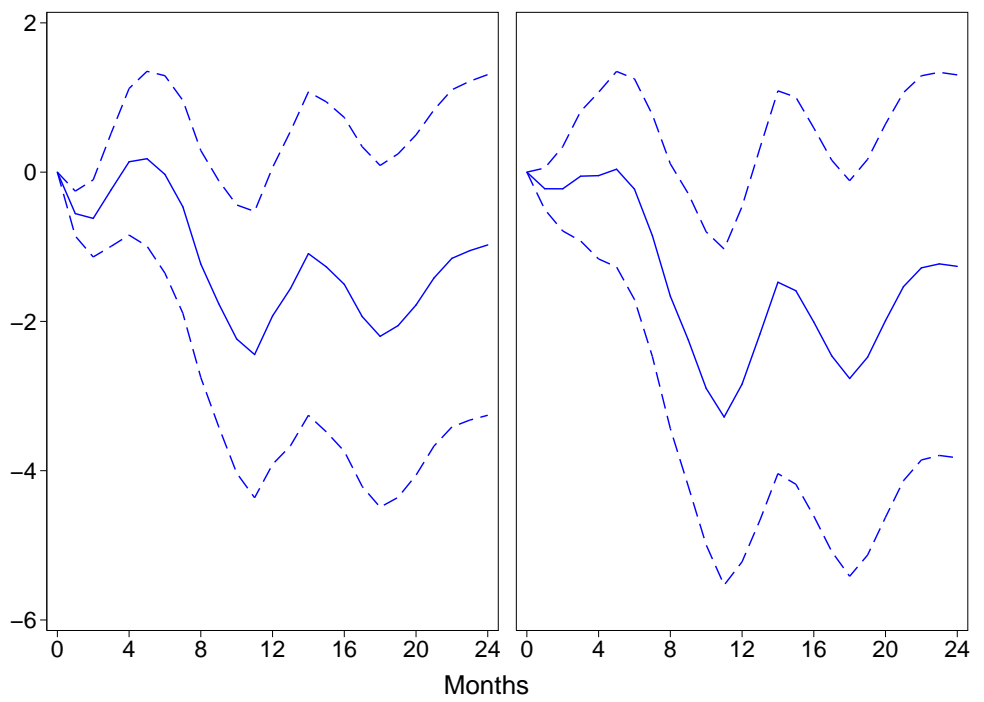

Panel B: Forecast error variance decomposition

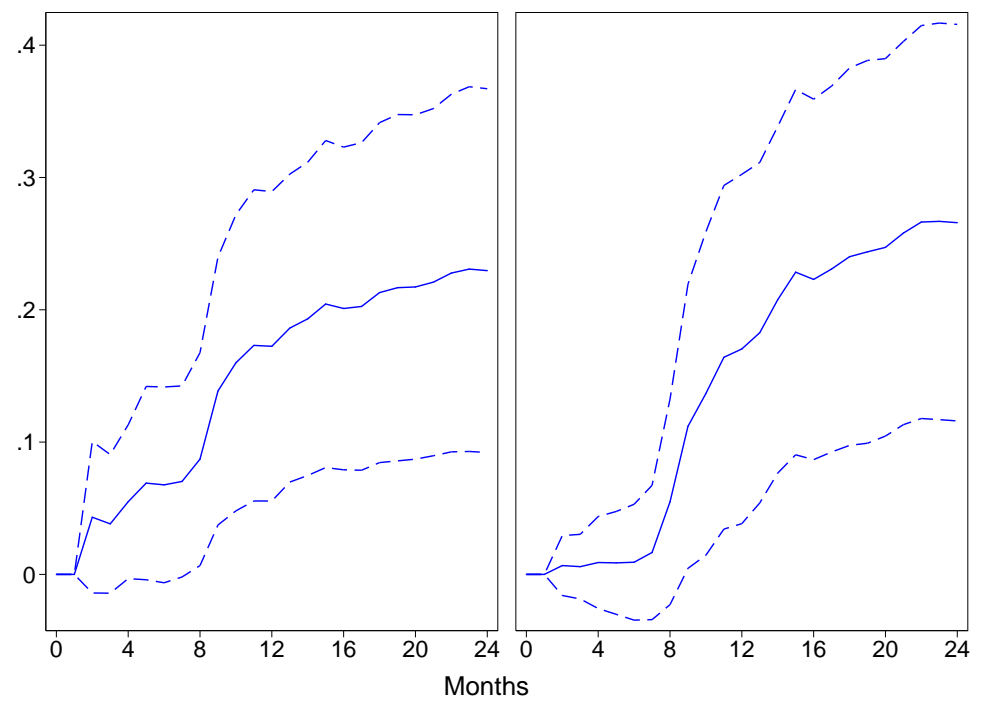

The figure plots the cumulative impulse response function and the forecast error variance decomposition from a VAR on monthly data for the wholesale price index, manufacturing output, manufacturing total hours, and the credit spread. Total hours equals employment times weekly hours. The left panels present the response of total hours and the right panels present the response of output. The sample period is July 1922 to June 1939. The shocks are identified based on shortrun restrictions with the credit spread series ordered last. The dashed-lines represent bootstrapped 95 percent confidence intervals. 
Figure 6: Responses to securities issuance

Panel A: Impulse response function (total hours and output)

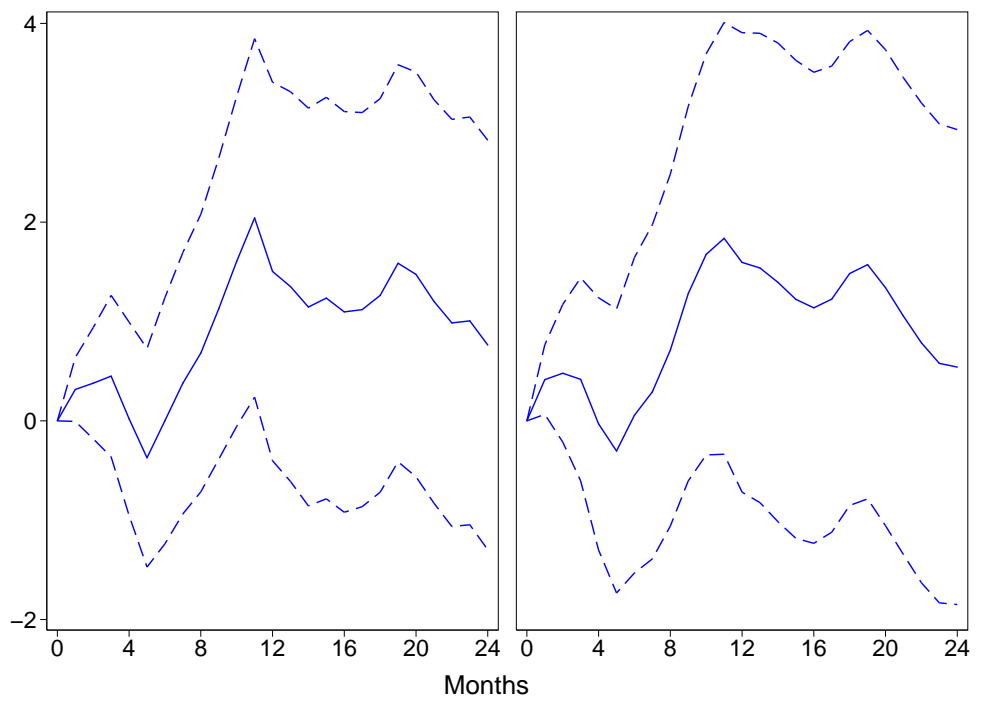

Panel B: Forecast error variance decomposition

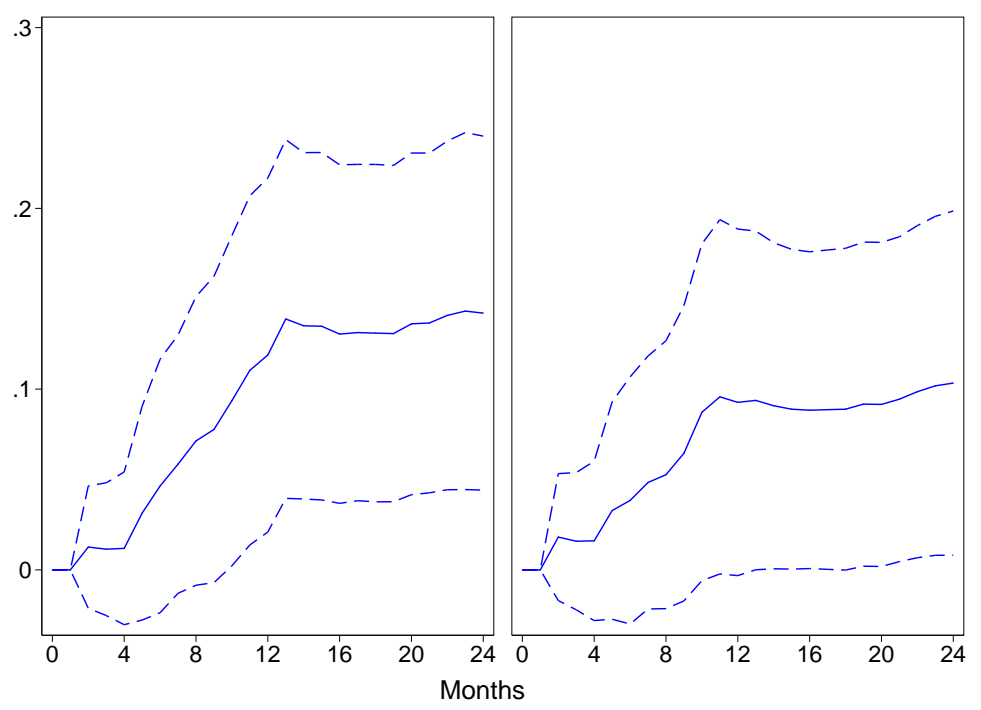

The figure plots the cumulative impulse response function and the forecast error variance decomposition from a VAR on monthly data for the wholesale price index, manufacturing output, manufacturing total hours, and total securities issuance. Total hours equals employment times weekly hours. The left panels present the response of total hours and the right panels present the response of output. The sample period is July 1922 to June 1939. The shocks are identified based on short-run restrictions with the securities issuance series ordered last. The dashed-lines represent bootstrapped 95 percent confidence intervals. 
Figure 7: Responses of durable goods sector employment and output

Panel A: Stock prices

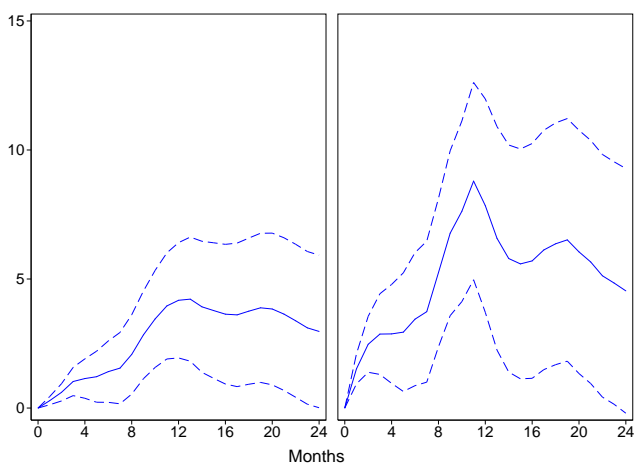

Panel B: Credit spreads

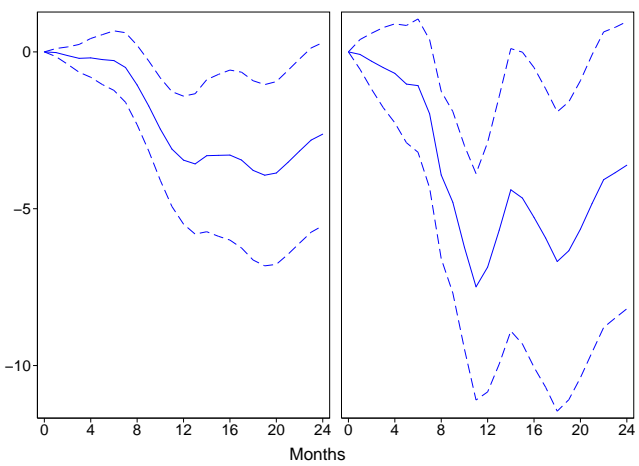

Panel C: Securities issuance

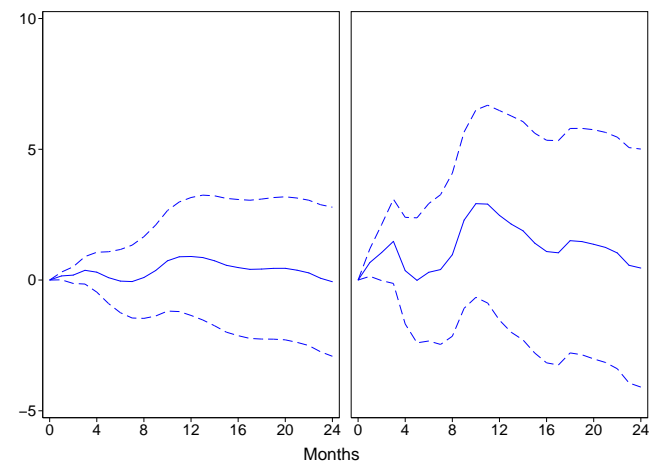

The figure plots the impulse response function from VARs using monthly data on the wholesale price index, durable goods production, durable goods sector employment and a financial system variable. Panels A, B, and C report the results with stock prices, credit spreads, and securities issuance, respectively, as the financial system variable. The sample period is January 1923 to June 1939. The left panels present the employment response and the right panels present the output response. The shocks are identified based on short-run restrictions with the financial market variable ordered last. The dashed-lines represent bootstrapped 95 percent confidence intervals. 
Figure 8: Responses of nondurable goods sector employment and output

Panel A: Stock prices

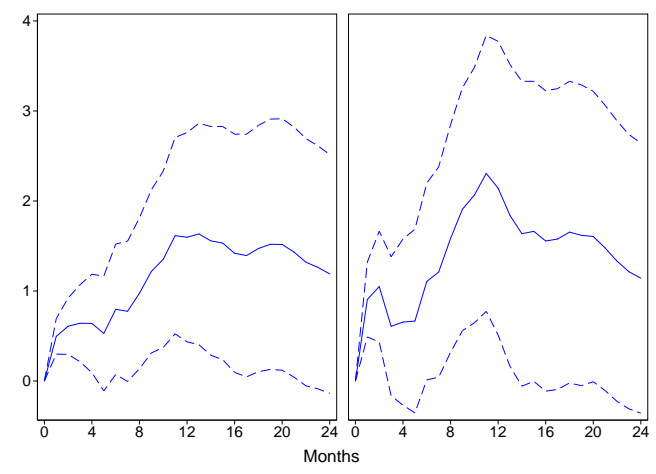

Panel B: Credit spreads

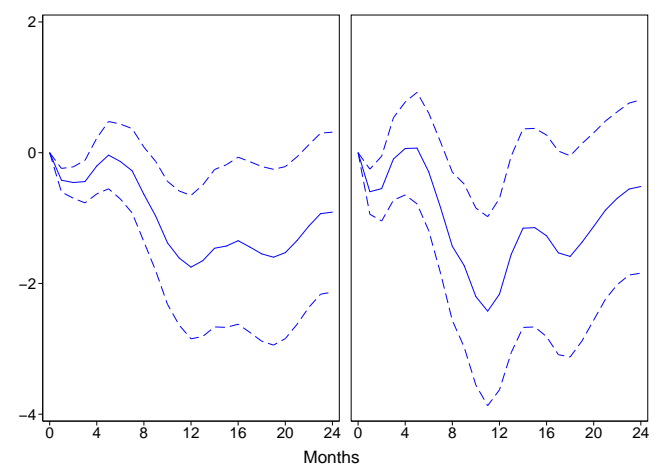

Panel C: Securities issuance

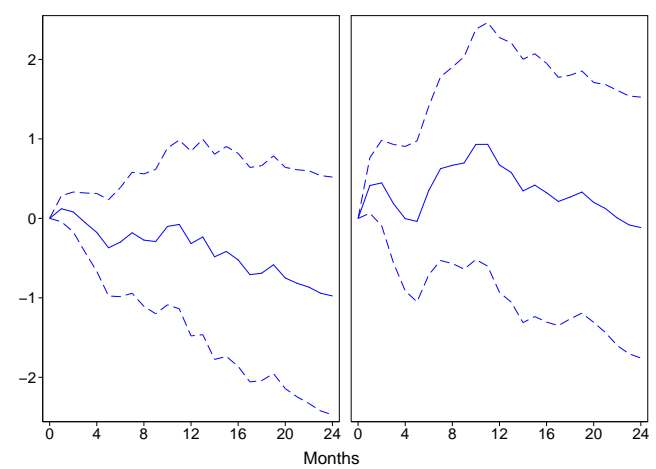

The figure plots the impulse response function from VARs using monthly data on the wholesale price index, nondurable goods production, nondurable goods sector employment and a financial system variable. Panels A, B, and C report the results with stock prices, credit spreads, and securities issuance, respectively, as the financial system variable. The sample period is January 1923 to June 1939. The left panels present the employment response and the right panels present the output response. The shocks are identified based on short-run restrictions with the financial market variable ordered last. The dashed-lines represent bootstrapped 95 percent confidence intervals. 
Figure 9: Responses of total hours and output to stock market volatility and stock prices

Panel A: Stock market volatility

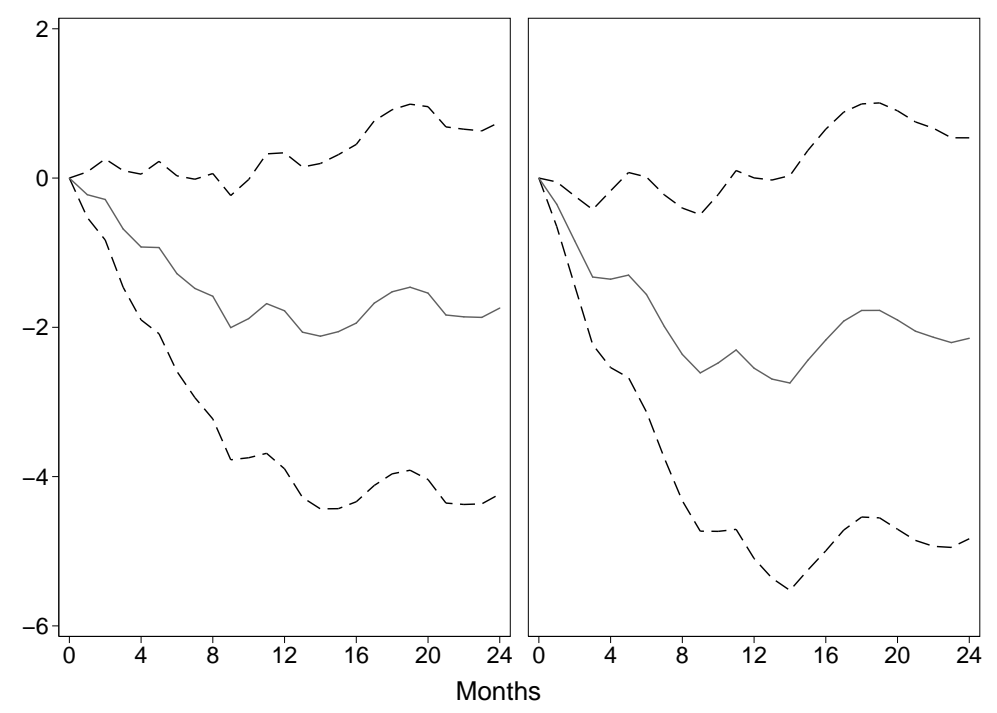

Panel B: Stock prices

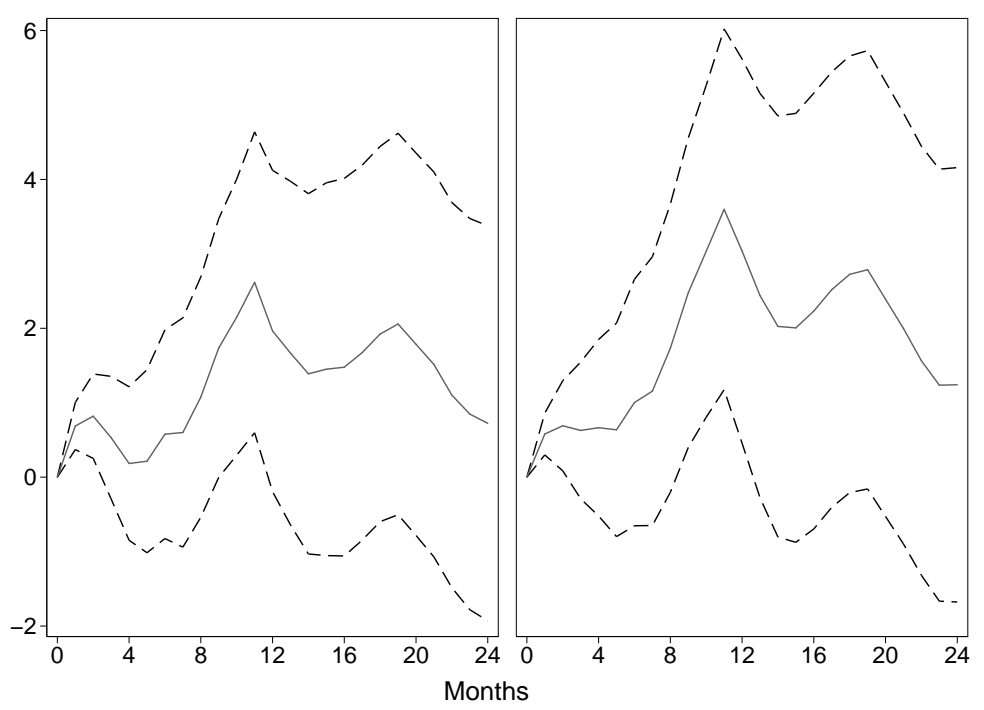

The figure plots the cumulative impulse response functions from a VAR on monthly data for the wholesale price index, manufacturing output, manufacturing total hours, stock market volatility, and real stock prices. Total hours equals employment times weekly hours. The left panels present the response of total hours and the right panels present the response of output. The sample period is July 1922 to June 1939. The shocks are identified based on short-run restrictions with the stock price series ordered last. The dashed-lines represent bootstrapped 95 percent confidence intervals. 